\title{
Seemingly divergent sea surface temperature proxy records in the central Mediterranean during the last deglaciation
}

\author{
M.-A. Sicre ${ }^{1}$, G. Siani ${ }^{2}$, D. Genty ${ }^{1}$, N. Kallel ${ }^{3}$, and L. Essallami ${ }^{4}$ \\ ${ }^{1}$ Laboratoire des Sciences du Climat et de l'Environnement, Domaine du CNRS - UMR8212, Avenue de la Terrasse, \\ Gif-sur-Yvette Cedex, France \\ ${ }^{2}$ Université Paris-Sud XI, Faculté des Sciences d'Orsay, 91405 Orsay, France \\ ${ }^{3}$ Faculté de Sfax, Faculté des Sciences de Sfax, Unité GEOGLOB, BP. 802, 3038, Sfax, Tunisia \\ ${ }^{4}$ Université de Gabès, Faculté des Sciences de Gabès, Gabès, Tunisia
}

Correspondence to: M.-A. Sicre (marie-alexandrine.sicre@1sce.ipsl.fr)

Received: 17 January 2013 - Published in Clim. Past Discuss.: 4 February 2013

Revised: 27 May 2013 - Accepted: 30 May 2013 - Published: 28 June 2013

\begin{abstract}
Sea surface temperatures (SSTs) were reconstructed over the last $25000 \mathrm{yr}$ using alkenone paleothermometry and planktonic foraminifera assemblages from two cores of the central Mediterranean Sea: the MD04-2797 core (Siculo-Tunisian channel) and the MD90-917 core (South Adriatic Sea). Comparison of the centennial scale structure of the two temperature signals during the last deglaciation period reveals significant differences in timing and amplitude. We suggest that seasonal changes likely account for seemingly proxy record divergences during abrupt transitions from glacial to interglacial climates and for the apparent short duration of the Younger Dryas (YD) depicted by the alkenone time series, a feature that has already been stressed in earlier studies on the Mediterranean deglaciation.
\end{abstract}

\section{Introduction}

The Mediterranean region is of particular interest because of its sensitivity to climate and environmental changes and their impacts on ecosystems and human population history. Lying at the boundary between mid-latitude and sub-tropical climates, the Mediterranean basin is subject to complex atmospheric teleconnections that have been variable in time (Lionello et al., 2008; Luterbacher et al., 2006). Today, the Mediterranean climate is strongly influenced by the North Atlantic Oscillation (NAO) in winter (Hurrell, 1995; Trigo et al., 2004), while in summer high-pressure systems develop as the Hadley cell circulation move northward producing the characteristic dry season of this region. El Niño and Asian monsoons would also affect summer precipitation variability, mostly in the Eastern Mediterranean. Changes of these climate regimes such as the mid-latitude storm tracks originating from the North Atlantic, or the position of the subtropical highs thus exerts influence on the Mediterranean temperatures and precipitations. Documentation of past temporal and spatial climate patterns contributes to improve understanding of the Mediterranean climate and predictions.

In this study we discuss seemingly divergent sea surface temperature (SST) reconstructions form the Central Mediterranean Sea over the last $25 \mathrm{kyr}$ obtained using foraminifera assemblages and alkenone paleothermometry, two important information sources to investigate past ocean variability. In the recent years, progress has been made to improve proxy calibrations but few existing comparison between proxy and instrumental time series (20th century) have shown that environmental or dynamical factors (e.g. sea ice) can introduce bias and make it difficult to decipher the climate signal embedded in proxy reconstructions (Conte et al., 2006; Rülhemann and Butzin, 2006; Sicre et al., 2011). Here, we examine the sequence of events that punctuated the last deglaciation period when insolation changes due to orbital forcing was a major climate driver. We present records of planktonic foraminifera and alkenone-derived SSTs as well as the $\delta^{18} \mathrm{O}$ of $G$. bulloides from the South Adriatic Sea and the central Siculo-Tunisian channel, some of which have been earlier published. We then compare these data to the isotope records of the high latitude Greenland ice (GISP2) 
Table 1. Depth-age model for the MD04-2797. Dates were calibrated using CALIB 6.0.

\begin{tabular}{lcrr}
\hline Depth cm & $\begin{array}{c}\text { Conventional } \\
{ }^{14} \mathrm{C} \\
\text { ages } \\
(\mathrm{yr} \mathrm{BP})\end{array}$ & $\begin{array}{c}\text { Error } \\
\pm 1 \sigma\end{array}$ & $\begin{array}{r}\text { Calibrated year BP } \\
\text { range } 1 \sigma\end{array}$ \\
& 1105 & 20 & \\
\hline 0 & 5493 & 95 & $5725-5929$ \\
80 & 6700 & 85 & $7156-7325$ \\
160 & 7523 & 81 & $7917-8017$ \\
199 & 8113 & 81 & $8419-8557$ \\
240 & 8888 & 110 & $9398-9556$ \\
330 & 10863 & 32 & $12458-12528$ \\
410 & 12728 & 173 & $13786-14246$ \\
470 & 13900 & 141 & $15495-16373$ \\
510 & 15590 & 50 & $18463-18986$ \\
610 & 17660 & 70 & $20287-20541$ \\
700 & 23415 & 163 & $27645-28113$ \\
940 & & & \\
\hline
\end{tabular}

and the nearby stalagmite of La Mine Cave (Tunisia) to understand the expression of centennial scale events of Termination I, i.e. the abrupt cold Younger Dryas (YD) and warm Bølling-Allerød (BA) in Mediterranean proxy records. A thorough regional comparison of marine and terrestrial proxy records is presented by Magny et al. (2013) to produce an integrated view of environmental changes in the central Mediterranean Sea and analyse their causes.

\section{Materials and methods}

\subsection{Site locations}

The MD90-917 core was collected during the PROMETE II cruise, performed aboard the French R/V Marion Dufresne, in the South Adriatic deep basin $\left(41^{\circ} 17 \mathrm{~N}, 17^{\circ} 37 \mathrm{E} ; 1010 \mathrm{~m}\right.$ water depth), in a wide circular-shaped depression detached from the Ionian Sea by the sill of the Otranto Strait $(780 \mathrm{~m})$ and bordered by the Italian and Albanian shelves (Van Straaten, 1970) (Fig. 1). The second core MD04-2797 $\left(36^{\circ} 57 \mathrm{~N}, 11^{\circ} 40 \mathrm{E} ; 771 \mathrm{~m}\right.$ water depth) was retrieved in the central part of the Sicilian-Tunisian channel during the IMAGES cruise in 2004, where Eastern and Western Mediterranean Sea waters exchange (Fig. 1). A description of hydrographic features at the core site can be found in Essalami et al. (2007) and Rouis-Zargouni et al. (2010).

\subsection{Age models}

The age model of the MD04-2797 core is based on 12 AMS ${ }^{14} \mathrm{C}$ dates (Table 1) performed on planktonic foraminifera in the size fraction $>150 \mu \mathrm{m}$ by the mass accelerator (AMS) ARTEMIS located in Gif-sur-Yvette, France. The ${ }^{14} \mathrm{C}$ ages were converted into calendar age using INTCAL09 (Reimer

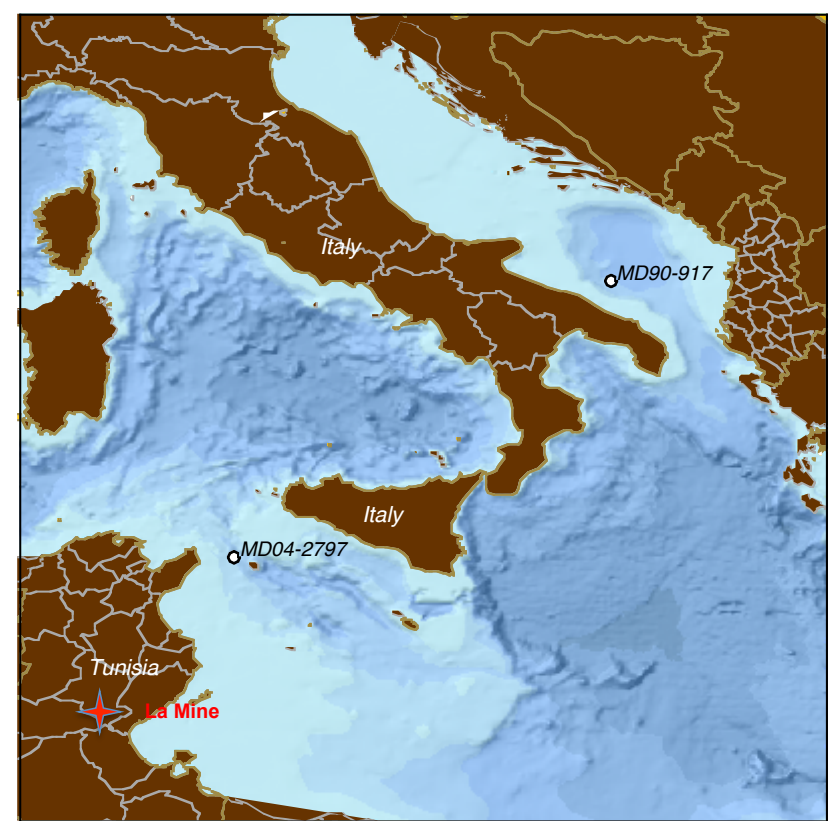

Fig. 1. Map showing the location of the two study cores of the Central Mediterranean Sea: MD90-917 (South Adriatic Sea) and MD04-2797 (Siculo-Tunisian Strait). The red star indicates the location where the La Mine stalagmite has been collecting.

et al., 2009) and the ${ }^{14} \mathrm{C}$ calibration Sofware CALIB6 (Stuiver and Reimer, 1993; Stuiver et al., 1998). We applied a marine reservoir correction of $400 \mathrm{yr}$ for Holocene, YD and Late Glacial sediments. The correction used for BA is 560 and $800 \mathrm{yr}$ for the Heinrich 1 (H1) and Older Dryas (Siani et al., 2001). Based on the age model, a sedimentation rate of $37 \mathrm{~cm} \mathrm{kyr}^{-1}$ during the Late Glacial, decreasing to $32 \mathrm{~cm} \mathrm{kyr}^{-1}$ for the Holocene, and a core-top age of 668 yr cal BP were calculated.

The age model of the MD90-917 core is built on 21 AMS ${ }^{14} \mathrm{C}$ dates (Table 2) performed on monospecific planktonic foraminifera in the size fraction $>150 \mu \mathrm{m}$ (Siani et al., 2010). Ages were corrected for a surface marine ${ }^{14} \mathrm{C}$ reservoir age of $400 \mathrm{yr}$, except for the early deglaciation where this value is double (Siani et al., 2000, 2001). The presence of 14 ash layers allowed refinement of the chronology (Zanchetta et al., 2008; Siani et al., 2004, 2006). The top core age is estimated to $582 \mathrm{yr}$. The sedimentation rate is approximately $35 \mathrm{~cm} \mathrm{kyr}^{-1}$ in the Late Glacial to Holocene portion resulting in a temporal resolution of $40 \mathrm{yr}$.

\subsection{SST reconstructions}

SSTs were determined using planktonic foraminifera assemblages $\left(\mathrm{SST}_{\text {foram }}\right)$ for April-May (AM-SST $\mathrm{T}_{\text {foram }}$ ) and October-November (ON-SST $\left.\mathrm{S}_{\text {foram }}\right)$. Each foraminifera sample in the $>150 \mu \mathrm{m}$ size fraction was split into 3001000 individuals for identification and counting following the taxonomy and ecological inferences of Pujol and 
Table 2. Depth-age model for the MD90-917. Dates were calibrated using CALIB 5.0.

\begin{tabular}{lrrr}
\hline Depth cm & $\begin{array}{c}\text { Conventional } \\
14 \text { C ages } \\
(\mathrm{yr} \text { BP })\end{array}$ & $\begin{array}{c}\text { Error } \\
\pm 1 \sigma\end{array}$ & $\begin{array}{r}\text { Calibrated year BP } \\
\text { range } 1 \sigma\end{array}$ \\
\hline $0-2$ & 1010 & 60 & $555-609$ \\
$140-142$ & 4180 & 70 & $4082-4290$ \\
$167-169$ & 4750 & 70 & $4855-4986$ \\
$175-177$ & 5000 & 70 & $5344-5466$ \\
$190-192$ & 5680 & 70 & $5990-6128$ \\
$230-232$ & 6920 & 90 & $7413-7511$ \\
$240-242$ & 7930 & 80 & $8171-8340$ \\
$250-252$ & 8170 & 70 & $8390-8482$ \\
$275-277$ & 10390 & 90 & $11304-11624$ \\
$295-297$ & 10800 & 90 & $12116-12399$ \\
$305-307$ & 10830 & 90 & $12225-12406$ \\
$315-317$ & 11140 & 90 & $12721-12853$ \\
$335-337$ & 11520 & 100 & $12939-13114$ \\
$395-397$ & 12660 & 110 & $13827-14063$ \\
$403-405$ & 13000 & 110 & $14595-15078$ \\
$423-425$ & 13270 & 100 & $15035-15366$ \\
$434-435$ & 13880 & 110 & $15232-15640$ \\
$490-492$ & 15050 & 90 & $16757-17234$ \\
$530-532$ & 16320 & 130 & $18978-19245$ \\
$540-542$ & 16800 & 140 & $19447-19607$ \\
$580-582$ & 17850 & 140 & $20400-20803$ \\
\hline
\end{tabular}

Vergnaud Grazzini (1995). Faunal composition of planktonic foraminifera assemblages was used to infer SSTs using the modern analogue technique (MAT) (Hutson, 1979; Prell, 1985) developed in the Mediterranean Sea by Kallel et al. (1997). The reference database is composed of 253 core top sediments, 130 from the Mediterranean Sea and 123 from the Atlantic Ocean (Kallel et al., 1997). Reliability of SST values is estimated from the square chord distance test (dissimilarity coefficient), which represents the mean degree of similarity between the sample and the best 10 modern analogues. For fossil samples with good modern analogues in the reference database, the dissimilarity is generally $<0.25$ (Prell, 1985). Above this value, the dissimilarity coefficient indicates no close modern analogues in the database and SST estimates are discarded. The calculated mean standard deviation of SSTs for MD90-917 core is estimated to be $0.7^{\circ} \mathrm{C}$ during the Holocene and has been $1.4^{\circ} \mathrm{C}$ since the Late Glacial period (Siani et al., 2013). For core MD04-2797, the mean SST standard deviation is estimated to be $1^{\circ} \mathrm{C}$.

SSTs were also derived from the $\mathrm{C}_{37}$ alkenone unsaturation index $U_{37}^{K^{\prime}}$. Alkenones are mainly produced by the ubiquitous marine coccolithophorid Emiliania huxleyi inhabiting surface waters that then become incorporated in marine sediments with no significant alteration of $U_{37}^{K^{\prime}}$ index value (see review by Grimalt et al., 2000; Sicre et al., 1999). Comparison between sediment trap and surface sediments from the NW Mediterranean Sea has shown that SSTs recorded in sediment are close to the annual mean (Ternois et al., 1996). This result essentially reflects the fact that spring and fall are the main seasons of alkenone production. The following equation, established by Conte et al. (2006), was used to translate $U_{37}^{K^{\prime}}$ into SSTs:

$T\left({ }^{\circ} \mathrm{C}\right)=-0.957+54.293\left(U_{37}^{K^{\prime}}\right)-52.894\left(U_{37}^{K^{\prime}}\right)^{2} 28.321\left(U_{37}^{K^{\prime}}\right)^{3}$.

Internal precision for alkenone-derived estimates is $0.3^{\circ} \mathrm{C}$. A detailed description of the laboratory protocol can be found in Ternois et al. (1997). A lower resolution alkenone SST record of the MD04-2797 core was published earlier by Essallami et al. (2007). Additional data have been generated in this study to increase temporal resolution.

\subsection{Oxygen isotopes}

Detailed oxygen isotope of the MD04-2797 core was obtained on planktonic foraminifera Globigerina bulloides and expressed in \%o versus VPDB (Vienna Pee Dee Belemnite standard) defined with respect to NBS19 calcite standard (Coplen, 1988). Between 6 and 20 shells were picked in the $250-315 \mu \mathrm{m}$ size range and analysed on a Finnigan $\Delta+$ and MAT251 mass spectrometers. The mean external reproducibility $(1 \sigma)$ of carbonate standards is $\pm 0.05 \%$, and measured NBS18 $\delta^{18} \mathrm{O}$ is $-23.2 \pm 0.2 \%$ VPDB. It has been shown that the most productive months of G. bulloides in the Mediterranean Sea are April-May (Pujol and Vergnaud Grazzini, 1995). A complete description of $\delta^{18} \mathrm{O}$ measurements can be found in Siani et al. (2013) for core MD90-917 and in Essalami et al. (2007) for core MD04-2797.

\section{Results}

\subsection{South Adriatic Sea MD90-917 core}

In the South Adriatic Sea, the $\delta^{18} \mathrm{O}$ of $G$. bulloides calcite range from mean glacial values of 3.5 to $0.97 \%$ at $\sim 8.5 \mathrm{kyr}$ (Fig. 2a, black curve). They then increase towards the present except for a decrease to $0.45 \%$ in the upper most sediments of the warmer Medieval Climatic Anomaly. Note that the centennial-scale events BA and YD are weakly expressed in the $\delta^{18} \mathrm{O}$ record as compared to Greenland ice. From 11.5 to $9.5 \mathrm{kyr}$ they also show a rather weak decrease, from 2.12 to $1.92 \%$.

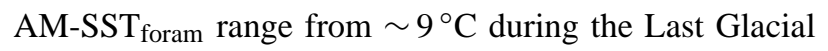
Maximum (LGM) (21-24 kyr) to $\sim 17^{\circ} \mathrm{C}$ Holocene values (Fig. 2a, dark blue curve) while ON-SST foram $_{\text {increase from }}$ $10.5^{\circ} \mathrm{C}$ to about $20^{\circ} \mathrm{C}$ (Fig. 2a, red curve). Core top values of $\mathrm{ON}_{-} \mathrm{SST}_{\text {foram }}\left(19^{\circ} \mathrm{C}\right)$ and $\mathrm{AM}-\mathrm{SST}_{\text {foram }}\left(17^{\circ} \mathrm{C}\right)$ are in good agreement with present-day average values for the same two months, 18.5 and $16^{\circ} \mathrm{C}$, respectively (Fichaut et

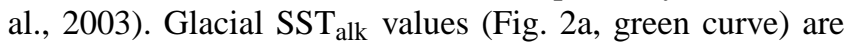
always warmer than $\mathrm{ON}-S S T_{\text {foram }}\left(13-15^{\circ} \mathrm{C}\right)$ and reach unexpectedly high values of nearly $19^{\circ} \mathrm{C}$ at $\sim 16.5 \mathrm{kyr}$, while 

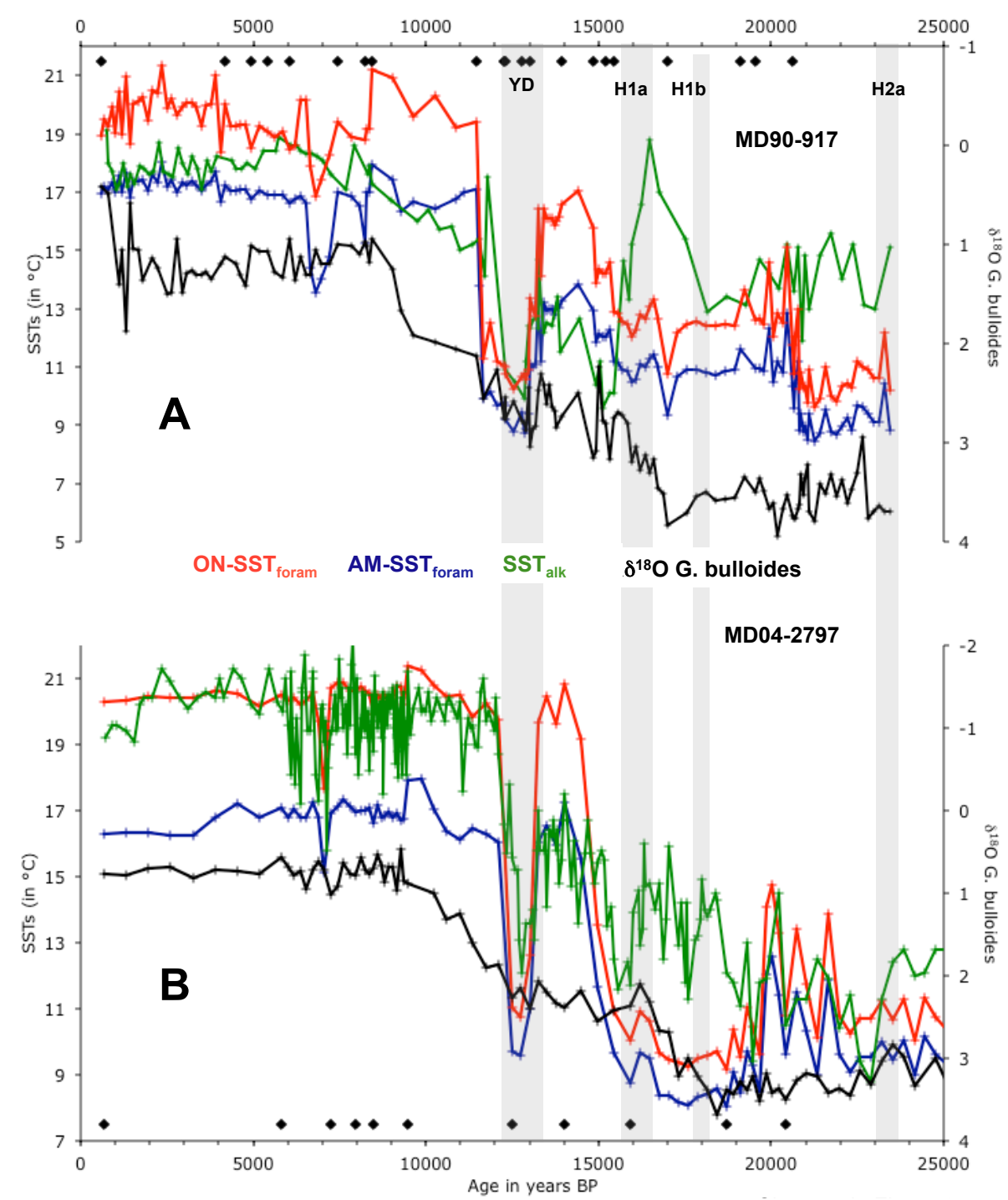

Fig. 2. SSTs derived from planktonic foraminifera assemblages for April-May (AM-SST $\mathrm{foram}_{\text {) }}$ and October-November ON-SST $\mathrm{T}_{\text {foram }}$ and alkenones $\left(\mathrm{SST}_{\mathrm{alk}}\right.$ ) and the $\delta^{18} \mathrm{O}$ determined in G. bulloides calcite (in \%o). (A) The upper panel shows the South Adriatic Sea core MD90-917 $\left(41^{\circ} \mathrm{N}, 17^{\circ} \mathrm{E} ;-1010.0 \mathrm{~m}\right)$ data $-\delta^{18} \mathrm{O}$ determined in G. bulloides calcite (in \%o) (Siani et al., 2004, 2010) - Sea surface temperatures (in ${ }^{\circ} \mathrm{C}$ ) derived from planktonic foraminifera assemblages for April-May and October-November (AM-SST foram and $\mathrm{ON}_{\text {-SST }}$ foram, respectively) (Siani et al., 2004, 2010) - Sea surface temperature derived from $\operatorname{SST}_{\text {alk }}$ (in ${ }^{\circ} \mathrm{C}$ ) (this study). (B) The lower panel shows the Siculo-Tunisian Strait core MD04-2797 $\left(36^{\circ} \mathrm{N}, 11^{\circ} \mathrm{E} ;-771 \mathrm{~m}\right)$ data. $-\delta^{18} \mathrm{O}$ determined in G. bulloides calcite (in \%o) (Essallami et al., 2007) - sea surface temperatures (in ${ }^{\circ} \mathrm{C}$ ) derived from planktonic foraminifera assemblages for April-May and October-November (AM-SST $\mathrm{Aram}_{\text {and }} \mathrm{ON}_{-}$ $\mathrm{SST}_{\text {foram}}$, respectively) (Essallami et al., 2007) - sea surface temperature derived from alkenones $\mathrm{SST}_{\text {alk }}$ (in ${ }^{\circ} \mathrm{C}$ ) (Essallami et al., 2007 and this study). Shaded areas in grey indicate the Younger Dryas (YD), the Heinrich stadial time intervals H1a (16 kyr), H1b (17.5 kyr) and H2a (23.5 kyr) according to Bard et al. (2000).

during the milder Holocene and BA they were close to AM$\mathrm{SST}_{\text {foram}}$. The $\mathrm{SST}_{\text {alk }}$ core top value of $\sim 18^{\circ} \mathrm{C}$ is consistent with the annual mean value of $18.2{ }^{\circ} \mathrm{C}$ at the core site (Fichaut et al., 2003). The amplitude of the deglacial warming is $6.5^{\circ} \mathrm{C}$ for $\mathrm{SST}_{\text {alk }}$ and $7.5^{\circ} \mathrm{C}$ for $\mathrm{SST}_{\text {foram }}$, while $\delta^{18} \mathrm{O}$ of $G$. bulloides decreases only by $0.5 \%$, a difference that underlines significant local salinity changes superimposed to the global ice volume. During the Holocene, $\mathrm{SST}_{\text {foram }}$ indicate a $2.5^{\circ} \mathrm{C}$ cooling at $8.2 \mathrm{kyr}$, and of $3{ }^{\circ} \mathrm{C}$ between 7.3 to $6.3 \mathrm{kyr}$ that are not seen in the $\mathrm{SST}_{\text {alk }}$ record.

\subsection{Siculo-Tunisian Strait MD04-2797 core}

In the central Siculo-Tunisian channel, glacial values of $\delta^{18} \mathrm{O}$ G. bulloides $(\sim 3.25 \%$ ) start to decrease around $18.5 \mathrm{kyr}$ (Fig. 2b, black curve). Between 16.5 and $12.8 \mathrm{kyr}$, values are relatively stable except for a slight enrichment of 
$0.5 \%$ between 15 and $16.5 \mathrm{kyr}$. After a subtle increase during the $\mathrm{YD}$, the $\delta^{18} \mathrm{O}$ decrease till $\sim 0.45 \%$ at $\sim 9.2 \mathrm{kyr}$.

$\mathrm{SST}_{\text {alk }}$ increase from glacial values of $\sim 8.5^{\circ} \mathrm{C}$ at $23 \mathrm{kyr}$ to $\sim 20-21^{\circ} \mathrm{C}$ during the Holocene (Fig. 2b, green curve). The core-top value of $\sim 19-19.5^{\circ} \mathrm{C}$ is close to mean annual $\left(19.3^{\circ} \mathrm{C}\right.$ ) (Fichaut et al., 2003). The ON-SST foram $\left(20.3^{\circ} \mathrm{C}\right)$ and $\mathrm{AM}-\mathrm{SST}_{\text {foram }}\left(16.3^{\circ} \mathrm{C}\right)$ values of the upper core also reveal a good agreement with present-day values of 20.2 and $16.3^{\circ} \mathrm{C}$, respectively (Fichaut et al., 2003). Except for the LGM, where $\mathrm{SST}_{\text {alk }}$ are similar to $\mathrm{SST}_{\text {foram }}$ (Fig. 2b, red and blue curves), they show warmer values than $\mathrm{ON}_{-} \mathrm{SST}_{\text {foram }}$ from $19 \mathrm{kyr}$ till the onset of the H1a, as earlier observed in the South Adriatic Sea. The higher resolution $\mathrm{SST}_{\text {alk }}$ signal also reveals imprint of millennial-scale event coolings that seems to coincide with massive iceberg discharges in the North Atlantic (Broecker et al., 1992), namely the H1a ( 15.5-16 kyr), H1b (17.6 kyr) and H2a (23.5 kyr) (Bard et al., 2000). Impact of these events on the hydrology of regions well outside the main belt of ice rafted debris (IRDs), such as the Mediterranean Sea, has been reported by Cacho et al. (1999). The presence of IRDs during H1a and H2a off the Iberian margin (Bard et al., 2000), may explain the more pronounced influence of these two Heinrich events on the Mediterranean surface water properties than H1b. Finally, it is noteworthy that $\mathrm{SST}_{\text {foram }}$ are similar during the BA and the Holocene, while $\mathrm{SST}_{\text {alk }}$ are $3{ }^{\circ} \mathrm{C}$ colder during the $\mathrm{BA}$ than the Holocene. This is in contrast with the South Adriatic Sea where both proxy records indicate warmer Holocene than BA SSTs by $4-5^{\circ} \mathrm{C}$. Another notable difference between the two proxy records is the onset of the final deglacial warming that occurs earlier in the $\mathrm{SST}_{\text {alk }}$ than $\mathrm{SST}_{\text {foram }}$ records. Finally, cooling at $\sim 7 \mathrm{kyr}$ in the South Adriatic Sea in $\mathrm{SST}_{\text {foram }}$ is also seen in the Siculo-Tunisian Strait but in both proxy records, yet with a different amplitude and duration.

\section{Discussion}

The SST reconstructions derived from the marine phytoplankton E. huxleyi and planktonic foraminifera assemblages show notable differences during the last deglaciation period that might express ecological features. The most remarkable discrepancy between our reconstructions is the anomalous warm $\mathrm{SST}_{\text {alk }}$ found in the South Adriatic Sea in the early phase of the deglaciation, centred at $\sim 16.5 \mathrm{kyr}$. Although we cannot rule out the contribution of advected detrital alkenones (Sicre et al., 2005; Rühlemann and Butzin, 2006), this anomaly most probably reflects a shift in the alkenone production. Today, in the western Mediterranean Sea and Adriatic Sea blooms of E. huxleyi occur in spring and fall (Ternois et al., 1996; Sicre et al., 1999; Totti et al., 2000). However, a recent comparison of proxy and instrumental 20th century time series in the North Atlantic has shown that environmental factors can alter alkenone production pattern at interannual to decadal timescale (Sicre et al.,
2011). Indeed, during the mid-1960s to early 1970s, large export of ice and freshwater from the Arctic into the subpolar North Atlantic resulted in enhanced stratification of the upper water column that favored warming of a thin surface water layer where small size nanophytoplankton such as coccolithophorid can grow. During these cold and icy years, alkenone SSTs were systematically biased towards warmer months compared to instrumental data suggesting a delayed alkenone production season caused by the presence of sea ice. Anomalously high $\mathrm{SST}_{\text {alk }}$ in the South Adriatic Sea could reflect environmental conditions during the early deglaciation period that may have favored water stratification. This time interval of warmer $\mathrm{SST}_{\text {alk }}$ coincides with lower diversity of planktonic foraminifera and unusually high abundances of Globorotalia scitula in the core (Siani et al., 2010). A sharp increase of G. scitula at around $16.3 \mathrm{kyr}$, contemporary to a decrease of $N$. pachyderma, has also been reported in the Tyrrhenian Sea (Sbaffi et al., 2004). Furthermore, investigations on G. scitula in Eastern Mediterranean sediments have shown a link between salinity and the abundances and morphotypes of G. scitula (Baumfalk et al., 1987). It is thus likely that during this time span, alkenone production was limited to a few weeks in summer and confined to nutrient depleted surface waters subsequent to enhanced stratification. Ice melting and subsequent continental runoff from surrounding rivers would have created conditions stabilizing the upper water column. In these sedimentary horizons, alkenones were less abundant and sometimes hardly detected. Highest $\delta^{18} \mathrm{O}$ occur when $\mathrm{SST}_{\text {foram }}$ are the lowest, around $17 \mathrm{kyr}$, suggesting that $G$. bulloides would have developed at the base of a shallow seasonal pycnocline, while a low alkenone production would have been possible in surface layers during the warmest months. Higher $\mathrm{SST}_{\mathrm{alk}}$ than $\mathrm{ON}-S S T_{\text {foram }}$ values between 19 and $16 \mathrm{kyr}$ (and the YD) at both sites of the Central Mediterranean Sea point to preferential summer alkenone production. In contrast, under milder BA and Holocene climates, $\mathrm{SST}_{\text {alk }}$ are close to AM$\mathrm{SST}_{\text {foram }}$ except for the Holocene in the Siculo-Tunisian Strait region where they are similar to $\mathrm{ON}_{-} \mathrm{SST}_{\text {foram }}$ again underlining different seasonal production. Overall, our observations suggest that hydrological changes can introduce bias in the proxy records by modifying the seasonal cycle and/or depth habitat of phyto- and zooplankton therefore complicating the interpretation of climate signals. Multiproxy records are thus necessary to pinpoint such changes that can be important and misleading in small basins such as the Mediterranean where continental climate exerts a strong influence on surface water properties.

Another substantial difference between proxy records is the onset of the YD, marked by a shift from $\mathrm{SST}_{\text {alk }}$ values close to $\mathrm{AM}-\mathrm{SST}_{\text {foram }}$ during the $\mathrm{BA}$, to values close to $\mathrm{ON}_{-} \mathrm{SST}_{\text {foram }}$ during the YD. While $\mathrm{SST}_{\text {foram }}$ remained low during the $\mathrm{YD}, \mathrm{SST}_{\text {alk }}$ become warmer than $\mathrm{ON}-\mathrm{SST}_{\text {foram }}$ pointing out that alkenone production progressively shifted to summer. This change could be responsible for the apparent 
shorter YD duration, a feature that has been previously documented in $\mathrm{SST}_{\text {alk }}$ signals of the Mediterranean Sea. Indeed, earlier warming of $\mathrm{SST}_{\text {alk }}$ by about $600 \mathrm{yr}$ and a brief YD (700 yr) compared to Greenland (1200-1300 yr, 12.8$11.5 \mathrm{kyr}$ ) has been underlined in the Alboran and Tyrrhenian seas (Cacho et al., 2001, 2002; Sbaffi et al., 2004), but none of these studies were multi-proxy, except for Sbaffi et al. (2001) who reported on MAT and $\mathrm{SST}_{\text {alk }}$ data from two Tyrrhenian Sea cores (BS79-38 and BS79-33). Even though the calibration used by these authors to translate $U_{37}^{K}$ into SSTs is different from our study, glacial $\mathrm{SST}_{\text {alk }}$ were generally higher than $\mathrm{SST}_{\text {foram }}$, while $\mathrm{SST}_{\text {foram }}$ during $\mathrm{BA}$ were similar to present-day values $\left(17^{\circ} \mathrm{C}\right)$ and $\mathrm{SST}_{\text {alk }}$ cooler by $3-4{ }^{\circ} \mathrm{C}$, as we also found in the Siculo-Tunisian Strait. Furthermore, although temporal resolution is lower than in our study, one of the two Tyrrhenian cores (BS79-38) also seems to show earlier $\mathrm{SST}_{\text {alk }}$ warming at the end of the YD. Overall, the BS79-38 core, and to a lower degree, the BS79-33 core, share resemblance with the Siculo-Tunisian Strait record. Another notable feature of the late deglaciation period is the brief cold reversal of $260 \mathrm{yr}$ seen in the $\mathrm{SST}_{\text {alk }}$ records and in the Greenland isotope record $(\sim 11.6 \mathrm{kyr})$, probably reflecting the Preboreal oscillation. This short episode has been reported by Cacho et al. $(2001,2002)$ and, within age model uncertainties, would be contemporary to the $\mathrm{SST}_{\text {alk }}$ decrease in the Ionian Sea documented by Emeis et al. (2000), when in the Levantine basin salinity and density decrease before $\mathrm{S} 1$ deposition. The following slower $\mathrm{SST}_{\text {alk }}$ warming in the South Adriatic Sea from 11.5 to $9.5 \mathrm{kyr}$ coincides with the lower rate decrease of $\delta^{18} \mathrm{O}$ of $G$. bulloides. In summary, while there seems to be some similarity between the South Adriatic and Ionian Sea deglaciation records, the SiculoTunisian channel shares a resemblance with the Tyrrhenian Sea (Cacho et al., 2001).

\section{Isotope signal in GISP2 and La Mine stalagmite (Tunisia)}

Comparison of $\mathrm{SST}_{\mathrm{alk}}$ with the reference GISP2 $\delta^{18} \mathrm{O}$ curve highlights differences between the North Atlantic and Mediterranean signals over the deglaciation period. During the last glacial, SST $_{\text {alk }}$ indicate warming between 19 and $16 \mathrm{kyr}$ in the Siculo-Tunisian channel and in the Adriatic Sea, while air over Greenland cooled (Fig. 3). After a sharp decline around the onset of the $\mathrm{BA}, \mathrm{SST}_{\mathrm{alk}}$ increase rapidly in the Siculo-Tunisian channel while in South Adriatic warming towards BA is more gradual. Similarly, $\mathrm{SST}_{\text {alk }}$ indicate a cooler early Holocene in the South Adriatic region resulting from a slower warming than the $\mathrm{SST}_{\text {foram }}$ since the end of the YD, as also seen in the Greenland ice core. Delayed Holocene Thermal Maximum (HTM) compared to orbitally forced insolation at high- to mid-latitudes has been attributed to the influence of remnant continental ice (Renssen et al., 2012). A late HTM in the South Adriatic Sea would thus be consistent with continental run off from melting ice being more important in the Adriatic Sea than in the
Siculo-Tunisian Strait site, which does not show clear evidence for a HTM as was also observed in the MD95-2043 site (Alboran Sea), lying in the Modified Atlantic Waters (Cacho et al., 1999). In contrast, the M40_SL78 core located in the northern Siculo-Tunisian basin indicate cooler early Holocene and a HTM around $8.5 \mathrm{kyr}\left(21^{\circ} \mathrm{C}\right)$ (Emeis and Dawson, 2003), which suggests that the northern and southern Siculo-Tunisian channel were affected differently by continental hydrology. In the Siculo-Tunisian Strait, the Allerød appears as warm as the Bølling and relatively stable.

The $\mathrm{SST}_{\text {alk }}$ warming during the YD seems to begin earlier in Siculo-Tunisian by $\sim 500 \mathrm{yr}$ than in southern Adriatic Sea, and $\sim 1000 \mathrm{yr}$ earlier than in the GISP2. Keeping in mind age model uncertainties, we can speculate that early warming of $\mathrm{SST}_{\text {alk }}$ in the Siculo-Tunisian Strait might reflect a more rapid return to interglacial conditions due to more pronounced subtropical influence in this sub-basin. To investigate this hypothesis, we compared our records to the $\mathrm{C}$ and $\mathrm{O}$ isotope signals of the Northern Tunisia stalagmite La Mine (Min-stm1) that provides a continuous climate record from $25 \mathrm{kyr}$ ago (Fig. 3). The $\delta^{13} \mathrm{C}$ variations in this stalagmite have been attributed to vegetation changes induced by temperature and soil humidity (Genty et al., 2006). The $\delta^{13} \mathrm{C}$ rise indicates a decline of the vegetation during the cold/dry YD that is not seen in the $\delta^{18} \mathrm{O}$. This cold reversal is followed by a gradual transition to the Preboreal period associated with climate amelioration and vegetation development towards the Holocene. The $\delta^{18} \mathrm{O}$ stalagmite record is different and shows warming starting around $16.4 \mathrm{kyr}$ progressing until a plateau during the YD. Interestingly, the $\delta^{18} \mathrm{O}$ of La Mine stalagmite share similarity to some degree with the $\delta^{18} \mathrm{O}$ of $G$. bulloides from the Siculo-Tunisian Strait suggesting that surface waters could have been major local sources of precipitation. Conversely, $\delta^{13} \mathrm{C}$ values tend to follow $\mathrm{SST}_{\mathrm{alk}}$ trends consistently with temperature being a controlling factor of vegetation and soil activities, but does not the early decrease of the $\mathrm{SST}_{\text {alk }}$, and rather parallel the $\delta^{18} \mathrm{O}$ at GISP2. We can therefore reasonably conclude that if $\mathrm{SST}_{\text {alk }}$ warming does occur earlier in the southern than in the northern central Mediterranean Sea, it most likely reflects ecological responses to different local environmental conditions.

\section{Conclusions}

The Siculo-Tunisian channel and Adriatic Sea surface water temperature signals reveal differences caused by local environmental conditions that likely modified the alkenone production season pattern (timing, amplitude and duration). While alkenone and foraminifera derived SSTs indicate rapid cooling at the onset of the YD synchronous to GISP2, final warming to the Holocene occurs seemingly earlier in the $\mathrm{SST}_{\text {alk }}$ than $\mathrm{SST}_{\text {foram }}$ leading to an apparent shorter duration YD, consistent with previously reports from the Ioanian and Tyrrhenian Sea. We suggest that this bias result 


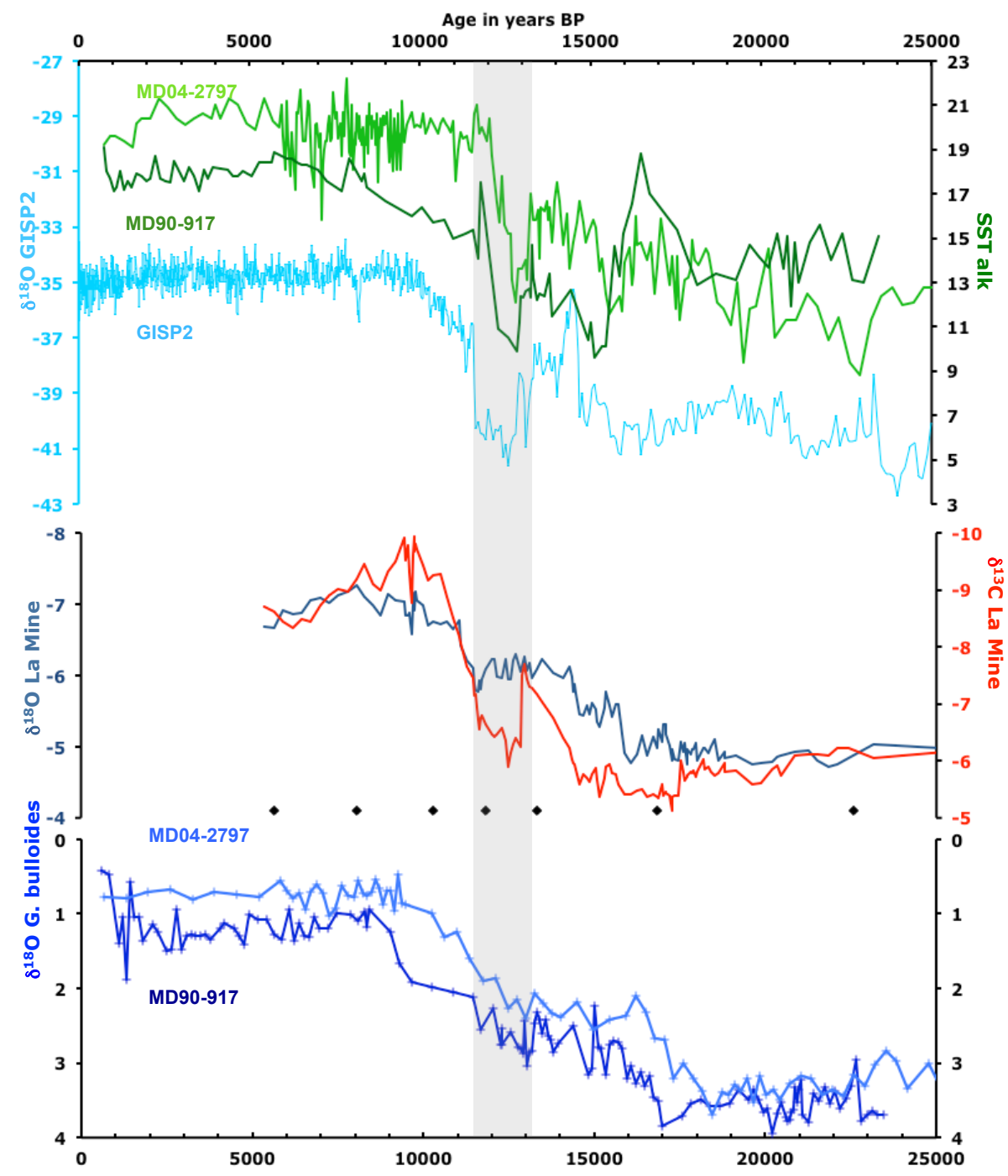

Fig. 3. Comparison between $\mathrm{SST}_{\mathrm{alk}}$ in the South Adriatic Sea (this study) and Siculo-Tunisian Strait (this study and Essallami et al., 2007) cores with the $\delta^{18} \mathrm{O}$ in the Greenland ice core GISP2, the $\mathrm{O}$ and C isotopes in La Mine stalagmite (Tunisia) (this study and Genty et al., 2006) and the $\delta^{18} \mathrm{O}$ in G. bulloides calcite from in the South Adriatic Sea (Siani et al., 2004, 2010) and Siculo-Tunisian Strait (Essallami et al., 2007) cores. Black diamons indicate U/Th dates performed on La Mine stalagmite.

from alkenone production shifting from spring during the $\mathrm{BA}$, to summer during the YD and back to spring during the Holocene, except for the Siculo-Tunisian Strait region where Holocene $\mathrm{SST}_{\text {alk }}$ are close to $\mathrm{ON}-\mathrm{SST}_{\text {foram. }}$. Impact of cold Heinrich stadials on surface water properties are well expressed in the Atlantic Modified Waters flowing along the northern African coast indicating stronger influence of the North Atlantic waters than in the South Adriatic Sea, where these hydrological features are concealed by river runoff resulting from melting of continental ice sheets.
Acknowledgements. Financial support for this project was provided by the ANR LAMA. We thank the Laboratoire de Mesure du Carbone 14, UMS 2572, ARTEMIS in Saclay for ${ }^{14} \mathrm{C}$ measurements by AMS in the frame of the National Service to CEA, CNRS, IRD, IRSN and the Ministère de la Culture et de la Communication. We thank B. Martrat, acting as a reviewer, for contributing constructive comments that aided in improving the manuscript.

Edited by: N. Combourieu Nebout

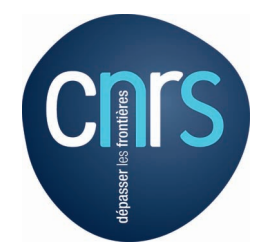

The publication of this article is financed by CNRS-INSU. 


\section{References}

Bard, E., Rostek, F., Turon, J.-L., and Gendreau, S.: Hydrological Impact of Heinrich Events in the Subtropical Northeast Atlantic, Science, 289, 1321-1324, 2000.

Baumfalk, Y. A., Troelstra, S. R., Ganssen, G., and Van Zanen, M. J. L.: Phenotypic variation of Globorotalia scitula (Foraminiferida) as a response to Pleistocene climatic fluctuations, Mar. Geol., 75, 231-240, 1987.

Broecker, W., Bond, G., Klas, M., Clark, E., and McManus, J.: Origin of the northern Atlantic's Heinrich events, Clim. Dynam., 6, 265-273, doi:10.1007/bf00193540, 1992.

Cacho, I., Grimalt, J. O., Pelejero, C., Canals, M., Sierro, F. J., Flores, J. A., and Shackleton, N. J.: Dansgaard-Oeschger and Heinrich event imprints in Alboran Sea paleotemperatures, Paleoceanography, 14, 698-705, 1999.

Cacho, I., Grimalt, J. O., Pelejero, C., Canals, M., Sbaffi, L., Shackleton, N. J., Schonfeld, J., and Zahn, R.: Variability of the Western Mediterranean Sea Surface temperatures during the last 25,000 years and its connection with the North Hemisphere climatic changes, Paleoceanography, 16, 40-52, 2001.

Cacho, I., Grimalt, J. O., and Canals, M.: Response of the Western Mediterranean Sea to rapid climate variability during the last 50,000 years: a molecular biomarker approach, J. Mar. Syst., 33, 253-272, 2002.

Conte, M. H., Sicre, M.-A., Rühlemann, C., Weber, J. C., Schulte, S., Schulz-Bull, D., and Blanz, T.: Global temperature calibration of the alkenone unsaturation index $\left(U_{37}^{K^{\prime}}\right)$ in surface waters and comparison with surface sediments, Geochem. Geophy. Geosy., 7, Q02005, doi:10.1029/2005GC001054, 2006.

Coplen, T. B.: Normalization of oxygen and hydrogen isotope data, Chem. Geol., 72, 293-297, 1988.

Emeis, K. C. and Dawson, A. G.: Holocene palaeoclimate records over Europe and the North Atlantic, Holocene 13, 305-309, doi:10.1191/0959683603hl622ed, 2003.

Emeis, K. C., Struck, U., Schulz, H. M., Rosenberg, R., Bernasconi, S., Erlenkeuser, H., Sakamoto, T., and Martinez-Ruiz, F.: Temperature and salinity variations of Mediterranean Sea surface water over the last 16,000 years from records of planktonic stable oxygen isotopes and alkenone unsaturation ratios, Paleogeogr. Paleocl., 158, 259-280, 2000.

Essallami, L., Sicre, M.-A., Kallel, N., Labeyrie, L., and Siani, G.: Hydrological changes in the Mediterranean Sea over the last 30,000 years, Geochem. Geophy. Geosy., 8, Q07002, doi:10.1029/2007GC001587, 2007.

Fichaut, M., Garcia, M. J., Giorgetti, A., Iona, A., Kuznetsov, A., Rixen, M., and Group, MEDAR/MEDATLAS 2002: A Mediterranean and Black Sea database for operational oceanography, in: Elsevier Oceanography Series, edited by: Dahlin, N. C. F. K. N. H. and Petersson, S. E., Elsevier, 645-648, 2003.

Genty, D., Blamart, D., Ghaleb, B., Plagnes, V., Causse, Ch., Bakalowicz, M., Zouari, K., Chlir, N., Hellstrom, J., Wainer, K., and Bourges, F.: Timing and dynamics of the last deglaciation from European and north African d13C stalagmite profiles comparison with chine and south hemisphere stalagmites, Quaternary Sci. Rev., 25, 2118-2142, 2006.
Grimalt, J. O., Rullkötter, J., Sicre, M.-A., Harvey, H. R., Farrington, J. W., Goni, M., Sawada, K., and Summons, R.: Modifications of the $\mathrm{C}_{37}$ Alkenone and Alkenoate composition in the water column and sediment: possible implications for sea surface temperature estimates in paleoceanography, Geochem. Geophy. Geosy., 1, 1031, doi:10.1029/2000GC000053, 2000.

Hurrell, J. W.: Decadal trends in the north Atlantic Oscillation: regional temperatures and precipitation, Science, 269, 676-679, 1995.

Huston, W. H.: The Aghulas current during the late Pleistocene: Analysis of Modern Analogs, Science, 207, 227-238, 1979.

Kallel, N., Paterne, M., Labeyrie, L., Duplessy, J.-C., and Arnold, M.: Temperature and Salinity records of the Tyrrhenian Sea during the last 18000 years, Paleogeogr. Paleocl., 135, 97-108, 1997.

Lionello, P., Planton, S., and Rodo, X.: Preface: trends and climate change in the Mediterranean region, Global Planet. Change, 63, 90-104, 2008.

Luterbacher, J., Xoplak, E., Casty, C., Wanner, H., Pauling, A., Küttel, M., Rutishauser, T., Brönnimann, S., Fischer, E., Fleitmann, D., Gonzalez-Rouco, F. J., García-Herrera, R., Barriendos, M., Rodrigo, F., Gonzalez-Hidalgo, J. C., Saz, M. A., Gimeno, L., Ribera, P., Brunet, M., Paeth, H., Rimbu, N., Felis, T., Jacobei, J., Dünkeloh, A., Zorita, E., Guiot, J., Türkes, M., Alcoforado, M. J., Trigo, R., Wheeler, D., Tett, S., Mann, M. E., Touchan, R., Shindell, D. T., Silenzi, S., Montagna, P., Camuffo, D., Mariotti, A., Nanni, T., Brunetti, M., Mauger, M., Zerefos, C., De Zolt, S., Lionello, P., Nunes, M. F., Rath, V., Beltrami, H., Garnier, E., and Ladurie, E. L. R.: Mediterranean climate variability over the last centuries: a review, in: The Mediterranean Climate: An Overview of the Main Characteristics and Issues, edited by: Lionello, P., Malanotte-Rizzoli, P., and Boscolo, R., Elsevier, Amsterdam, 27-148, 2006.

Magny, M., Combourieu Nebout, N., de Beaulieu, J. L., BoutRoumazeilles, V., Colombaroli, D., Desprat, S., Francke, A., Joannin, S., Peyron, O., Revel, M., Sadori, L., Siani, G., Sicre, M. A., Samartin, S., Simonneau, A., Tinner, W., Vannière, B., Wagner, B., Zanchetta, G., Anselmetti, F., Brugiapaglia, E., Chapron, E., Debret, M., Desmet, M., Didier, J., Essallami, L., Galop, D., Gilli, A., Haas, J. N., Kallel, N., Millet, L., Stock, A., Turon, J. L., and Wirth, S.: North-south palaeohydrological contrasts in the central Mediterranean during the Holocene: tentative synthesis and working hypotheses, Clim. Past Discuss., 9, 1901-1967, doi:10.5194/cpd-9-1901-2013, 2013.

Prell, W.: The stability of low latitudes sea surface temperature: An evaluation of the CLIMAP reconstitution with emphasis on the positive SST anomalies, Technical report RT025, United States Department of Energy, Washington, DC, 60 pp., 1985.

Pujol, C. and Vergnaud-Grazzini, C.: Distribution patterns of live planktonic foraminifers as related to regional hydrography and productive systems of the Mediterranean Sea, Mar. Micropaleontol., 25, 187-217, 1995.

Reimer, P. J., Baillie, M. G. L., Bard, E., Bayliss, A., Beck, J. W., Blackwell, P. G., Ramsey, C. B., Buck, C. E., Burr, G. S., Edwards, R. L., Friedrich, M., Grootes, P. M., Guilderson, T. P., Hajdas, I., Heaton, T. J., Hogg, A. G., Hughen, K. A., Kaiser, K. F., Kromer, B., McCormac, F. G., Manning, S. W., Reimer, R. W., Richards, D. A., Southon, J. R., Talamo, S., Turney, C. S. M., van der Plicht, J., and Weyhenmeye, C. E.: Intcal09 and 
Marine09 Radiocarbon Age Calibration Curves, 0-50,000 Years Cal BP, Radiocarbon, 51, 1111-1150, 2009.

Renssen, H., Seppä, H., Crosta, X., Goosse, H., and Roche, D. M.: Global characterization of the Holocene Thermal Maximum, Quaternary Sci. Rev., 48, 7-19, doi:10.1016/j.quascirev.2012.05.022, 2012.

Rouis-Zargouni, I., Turon, J.-L., Londeix, L., Essallami, L., Kallel, N., and Sicre, M.-A.: Environmental and climatic changes in the central Mediterranean Sea (Siculo-Tunisian Strait) during the last $30-0 \mathrm{ka}$ based on dinoflagellate cyst and planktonic foraminifera assemblages, Palaeogeogr. Palaeocl., 285, 17-29, 2010.

Rühlemann, C. and Butzin, M.: Alkenone temperature anomalies in the Brazil-Malvinas Confluence area caused bylateral advection of suspended particulate material, Geochem. Geophy. Geosy., 7, Q10015, doi:10.1029/2006GC001251, 2006.

Sbaffi, L., Wezel, F. C., Kallel, N., Paterne, M., Cacho, I., Ziveri, P., and Schackleton, N.: Response of the pelagic environment to palaeoclimatic changes in the central Mediterranean Sea during the Late Quaternary, Mar. Geol., 178, 39-62, 2001.

Sbaffi, L., Wezel, F. C., Curzi, G., and Zoppi, U.: Millennialto centennial-scale palaeoclimatic variations during Termination I and the Holocene in the central Mediterranean Sea, Global Planet. Change, 40, 201-217, 2004.

Siani, G., Paterne, M., Arnold, M., Bard, E., Métivier, B., Tisnerat, N., and Bassinot, F.: Radiocarbon reservoir ages in the Mediterranean Sea and Black Sea coastal waters, Radiocarbon, 42, 271280, 2000.

Siani, G., Paterne, M., Michel, E., Sulpizio, R., Sbrana, A., Arnold, M., and Haddad, G.: Mediterranean sea-surface radiocarbon reservoir age changes since the last glacial maximum, Science, 294, 1917-1920, 2001.

Siani, G., Sulpizio, R., Paterne, M., and Sbrana, A.: Tephrostratigraphy study for the last $18,000{ }^{14} \mathrm{C}$ years in a deep-sea sediment sequence for the South Adriatic, Quaternary Sci. Rev., 23, 24852500, 2004.

Siani, G., Sulpizio, R., and Paterne, M.: Application of marine tephrochronology to paleoclimatic studies: the example of the Central Mediterranean Sea, Acta Vulcanol., 18, 47-54, 2006.

Siani, G., Paterne, M., and Colin, C.: Late glacial to Holocene planktic foraminifera bioevents and climatic records in the South Adriatic Sea, J. Quaternary Sci., 25, 808-821, 2010.
Siani, G., Magny, M., Paterne, M., Debret, M., and Fontugne, M.: Paleohydrology reconstruction and Holocene climate variability in the South Adriatic Sea, Clim. Past, 9, 499-515, doi:10.5194/cp-9-499-2013, 2013.

Sicre, M.-A., Ternois, Y., Miquel, J.-C., and Marty, J.-C.: Alkenones in the Mediterranean sea: interannual variability and vertical transfer, Geophys. Res. Lett., 26, 1735-1738, 1999.

Sicre, M.-A., Labeyrie, L., Ezat, U., Duprat, J. Turon, J.-L., Schmidt, S., Michel, E., and Mazaud, A.: Southern Indian Ocean response to Northern Hemisphere Heinrich events, Earth Planet. Sc. Lett., 240, 724-731, 2005.

Sicre, M.-A., Hall, I., Mignot, J., Khodri, M., Ezat, U., Truong, M.X., Eiríksson, J., and Knudsen, K.-L.: Sea surface temperature variability in the subpolar Atlantic over the last two millennia, Paleoceanography, 26, PA4218, doi:10.1029/2011PA002169, 2011.

Stuiver, M. and Reimer, P. J.: Extended ${ }^{14} \mathrm{C}$ database and revised calib 3.0 ${ }^{14} \mathrm{C}$ age calibration program, Radiocarbon $35,215-230$, 1993.

Stuiver, M., Reimer, P. J., Bard, E., Beck, W., Burr, G. S., Hughen, K. A., Kromer, B., McCormac, F. G., and van der Spuk, M.: INTCAL98 radiocarbon age calibration 24,000 cal bp, Radiocarbon, 40, 1041-1083, 1998.

Ternois, Y., Sicre, M.-A., Boireau, A., Marty, J.-C., and Miquel, J.C.: Production pattern of alkenones in the Mediterranean Sea, Geophys. Res. Lett., 23, 3171-3174, 1996.

Ternois, Y., Sicre, M.-A., Boireau, A., Conte, M. H., and Eglinton, G.: Evaluation of long-chain alkenones as paleo-temperature indicators in the Mediterranean Sea, Deep-Sea Res., 44, 271-286, 1997.

Totti, C., Civitarese, G., Acri, F., Barletta, D., Candelari, G., Paschini, E., and Solazzi, A.: Seasonal variability of phytoplankton populations in the middle Adriatic sub-basin, J. Plankton Res., 22, 1735-1756, 2000.

Trigo, R. M., Trigo, I. F., DaCamara, C. C., and Osborn, T. J.: Climate impact of the European winter blocking episodes from the NCEP/NCAR Reanalyses, Clim. Dynam., 23, 17-28, 2004.

Van Straaten, L. M. J. U.: Holocene and late-Pleistocene sedimentation in the Adriatic Sea, Geolog. Rundschau, 60, 106-131, 1970

Zanchetta, G., Sulpizio, R., Giaccio, B., Siani, G., Paterne, M., Wulf, S., and D'Orazio M.: The Y-3 Tephra: a last glacial stratigraphic marker for the central Mediterranean basin, J. Volcanol. Geoth. Res., 177, 145-154, 2008. 